\title{
Measurement of the MOOC Phenomenon by Pre-Service Teachers: A Descriptive Case Study
}

\author{
José Gómez-Galán ${ }^{1,2, *}$, Cristina Lázaro-Pérez ${ }^{3}$ [ , José Ángel Martínez-López ${ }^{4}$ and \\ Eloy López-Meneses ${ }^{5,6}$ (D) \\ 1 Department of Education, University of Extremadura, Avda. de Elvas, s/n, 06006 Badajoz, Spain \\ College of Education, Ana G. Méndez University, Cupey Campus, San Juan, PR 00926, USA \\ 3 Department of Sociology, University of Murcia, C/Campus Universitario, 11, 30100 Murcia, Spain; \\ cristina.lazaro2@um.es \\ 4 Department of Social Work and Social Services, University of Murcia, Avda. Teniente Flomesta, 5, \\ 30003 Murcia, Spain; jaml@um.es \\ 5 Department of Education and Social Psychology, Faculty of Social Sciences, University Pablo de Olavide, \\ 41013 Seville, Spain; elopmen@upo.es \\ 6 Research Institute in Social Sciences and Education, Vice-Rectory for Research and Postgraduate, \\ University of Atacama, Copiapó 1530000, Chile \\ * Correspondence: jogomez@uagm.edu
}

Received: 23 July 2020; Accepted: 18 August 2020; Published: 20 August 2020 updates

\begin{abstract}
The main objective of this research is to establish the measurement of pre-service teachers on the MOOC phenomenon, one of the most important manifestations within the processes of on-line education that have emerged under the protection of the digital paradigm. The research methodology used was of an exploratory, qualitative, and descriptive nature. It falls within the generic scope of qualitative research methods of an ethnographic nature through the analysis of learning objects and interventions in the network. The sample $(n=218)$ was composed of students from the educational field, who took a subject focused on ICT applied to education, over several academic years. Using the edublog as a digital and documentary source, a total of 1962 frequencies were collected referring to the advantages (1052 frequencies) and limitations (910 frequencies) that they determined when carrying out these courses. As main results, it is worth mentioning that pre-service teachers consider MOOC courses valuable as teaching models in socio-educational contexts. They offer unquestionable advantages such as free of charge usage, training for disadvantaged groups, flexible hours, etc. However, their disadvantages are also important. For example, it is considered that these courses do not adequately follow up on the student, that the materials they offer are not very innovative, or also that the evaluation of the learning is inadequate. It is interesting to note that the main problems identified are of a pedagogical, not technical, nature.
\end{abstract}

Keywords: MOOC; higher education; online teaching; ICT; teacher training; socio-educational environments; distance learning

\section{Introduction}

The integration of information and communication technologies (ICT) in training contexts is one of the greatest challenges in higher education today [1-3]. The digitization and virtualization of the teaching-learning processes in the university world pose different challenges that must be met [4-8]. The digital paradigm has offered a new educational setting. The existence of multiple interactive and participatory technologies contribute to an individual learning experience but, at the same time, with multiple social connections that in many cases contribute to the motivation and 
active participation of the student $[9,10]$. Different educational and training models are being created, unrelated to what educational structures were just a few decades ago, a very short time in the whole of human history [11]. In this sense, there is no doubt that technology has a constant presence in our current life, with social networks as relational contexts or content repositories as collaborative spaces that demonstrate the development of the creativity of its users [12-15].

We live in a society that, due to its current dynamics, requires that educational systems around the world rethink the vision of future professionals who want to train according to global economic development and the demands of the ever-changing labor market; putting aside the traditional teaching model based on the transmission and memorization of knowledge, in favor of other methodologies that allow students to acquire a set of knowledge, skills and attitudes to apply them in a close and realistic work setting [16]. The socio-educational functions of today's education should be geared towards preparing future citizens to understand and interpret the political, economic and cultural complexity, navigate in uncertainty, develop previously unknown jobs, participate in the collective life of a global and local world in dizzying and permanent changes $[17,18]$. Likewise, teacher training should not be oblivious to the changes that occur in the society of the 21st century. This must be in tune with them and prepare future teachers to be able to include digital technologies in a pertinent, critical and reflective way in their training practices [19-23]. The motivational aspect is also fundamental in the framework of ICTs [23,24]. Under all these technological optics MOOC courses arise. The acronym MOOC literally translates to Massive Open Online Course.

This term was first used in 2008 to describe an online course developed by George Siemens and Stephen Downes. The course was followed free of charge and without accreditation by 2300 users via the Internet, although only 25 students enrolled. However, the first MOOC course that would collect the main characteristics of the phenomenon was one focused on Artificial Intelligence that was offered by Stanford University in 2011 and had tens of thousands of students enrolled [25,26]. One of the authors of this course was Sebastián Thrun, who, realizing the great potential and the strong impact that this new educational modality was causing, developed his own platform (Udacity). From that moment, many professors from prestigious universities continued in this line. Some of them, such as Daphne Koller and Andrew Ng, founded the MOOC platform called Coursera [27]. Such was the impact of the MOOC that in 2012 the article "The Year of the MOOC" was published in The New York Times. This led some authors, such as Regalado [28], to affirm that the MOOC course is the most important technological innovation in education in the last two hundred years.

However, if we look at the analysis carried out by Liyanagunawardena, Adams and Williams [29] on the most important scientific contributions on MOOC courses, it is easy to determine that they focus above all on highlighting their rapid expansion, well above their specific characteristics and especially didactics [30,31]. However, the most relevant dimension should be the pedagogical one. We should not forget that these are online courses, which require profound changes at the methodological level in relation to what teachers usually do in face-to-face teaching. These courses, from a didactic perspective, cannot only be a reflection of classical methodologies. They must take advantage of all the power offered by today's technological intra-structures to create innovative activities that favor the participation and interaction of all students in these virtual scenarios. In this sense, an open curriculum emerges in which teachers must generate individual and collective learning opportunities to perform tasks and skills, as well as develop students' abilities and competencies in accordance with Higher Education standards [32-35]. This is currently in wide debate within the context of outcomes-based education (OBE), which can have so much connection in the evolution of MOOC courses [36,37]. This phenomenon, therefore, remains one of the most studied and that arouses the most interest on an international scale, regardless of whether the moments of this formidable hatching have passed. Nowadays it is much more interesting to know its characteristics, especially didactic and pedagogical, that can really measure its methodological impact in the transformative processes of Higher Education. 


\section{Background}

It is important to point out, however, because it has been so widely studied and tested, that there is little preparation of teachers in Higher Education with regard to ICTs, which would undoubtedly make it difficult to speak of revolutionary teaching methodologies [38-40]. Too many myths have been created in recent years about the impact of ICT on education and digital literacy [41]. Of course, the appearance of MOOCs and their rapid dissemination can contribute to improving teacher training, especially from a didactic point of view. Thus, the importance does not lie in the use of new technologies, but in the use of these tools in an appropriate way so that students participate more actively and intensively in their training [42]. That learning, in short, and regardless of the context in which it is found, is the best possible. In this sense, the MOOC phenomenon has not been so innovative [43]. Despite presenting novel features-some of which were only experimental or that were in the process of being implemented-these courses are mainly based on traditional elements and are very simple in their structure. It is true that in order to offer them it is necessary to have a good technological base that allows creating the virtual environments in which they are developed, but globally they do not offer exclusive methodological innovations.

There are doubts about connectivism, one of the characteristics that has been assigned to MOOC courses. Although, among other authors, Siemens [44,45] has defended the benefits that connectivism offers in the educational process, where the interaction that people carry out would acquire greater importance than the content that is taught, there is no reliable demonstration of this fact. On the contrary, it is easy to find positions that affirm that these benefits are not obtained through the interconnection that takes place between the subjects, but rather thanks to the perception that the students have of this educational process [46]. Clará and Barberá [47] consider connectivism too problematic, arguing that they must bet on another type of methodology that is more consistent and adequate. It is common to find opinions both for and against its results [29,48-50], and today it is far from reaching a consensus on this matter. Precisely, the fact that today there are different types of MOOC courses depends, above all, on the connectivist characteristics they present. We can highlight the cMOOC (based on learning in networks based on connectivist postulates), xMOOC (although applied in networks it relies on traditional learning models) and $\mathrm{tMOOC}$, considering the latter as a hybrid model of the previous ones, as it has as a fundamental element the performance of tasks by the student [51-53]. However, in practice, there are not many differences in terms of results or research that can demonstrate that these typologies are actually applied based on their theoretical assumptions. Nor really specify the degree of connectivism present in a MOOC course.

However, despite this disappointment on the part of many experts, the development of MOOCs continues to be a booming phenomenon worldwide [11,54]. They emphasize the use of social networks (Facebook, Twitter, etc.) that consolidate these learning communities. In addition to social networks, those involved in the learning community can take advantage of content aggregation (RSS, for example) to share information, thematic or tangential materials, and learning strategies. Its fundamental characteristics are [55]: free training modalities, supported by audiovisual content, without limit of students and use collaborative and participatory methodological strategies. On the other hand, MOOCs are modern teaching-learning resources, with a high potential for the dissemination of knowledge because they are based on social networks [56]. They also expand access to training by offering learning opportunities regardless of affiliation with a particular institution. They are very interesting because they allow anyone to continue training throughout their lives, and it can serve as a way for teachers to promote their professional development. Also, in agreement with García-Sastre, Idrissi, Ortega and Gómez-Sánchez [57], it presents great potential to allow access to higher education to any student for free who has the possibility of accessing the Internet. In addition, they offer multiple advantages at the educational level, such as ubiquity, free, credibility and quality [58]. On the other hand, various authors [59-61] describe several of the weaknesses of this training modality, including: high dropout rates; lack of feedback; low interaction; there is no reliable verification of learning outcomes and peer assessments and a wide variety of topics predominate, but without an explicit 
curriculum. Ultimately, MOOC courses can be considered to be a large-scale, modular and adaptive training solution to changes or new social needs [62]. Likewise, although the evaluation has aroused a great didactic motivation and generated different models and proposals, ranging from questionnaires corrected in an automated way, peer evaluation, or e-portfolios, it is of vital importance to study the level of cognitive competence. In this sense, Dawna, Eleanore, Williams and Brooks [63] carry out pilot studies related to the optimal automatic correction related to this type of evaluative test. Similarly, as indicated by López-Meneses, Vázquez-Cano and Román [64] there is a progressive increase in scientific documents related to this issue worldwide from 2013 to the present. In this sense, as Shah [65] points out, these emerging training trends have become very popular, with thousands of courses produced annually. Ultimately, MOOCs can be considered as new socio-virtual environments for sustainable educational development and can lead to a turning point in the didactic ecosystem of Higher Education [66].

\section{Materials and Methods}

\subsection{Scenario Research, Sample and Objectives}

Although in recent years there have been multiple studies and research on MOOC courses, which have covered practically all its possible dimensions, we consider that there is one of them that should be further explored due to its great interest. By this, we mean understanding better how their main users value them: students. In addition, and although its defining characteristic of open courses makes it possible for anyone of any age to follow them, it is especially relevant for us to establish the assessment made of this phenomenon by Higher Education students and, specifically, in the scenario of future professionals of teaching. That is why we have carried out this research in degrees related to education, after a theoretical presentation and practical experience that students had to carry out by taking MOOC courses.

The study was carried out for five years, from 2015 to 2019, at the Pablo de Olavide University, in Seville (Spain), applied to pre-service teachers students of the subject "ICT in Social Education" (of the Degree in Social Education, 7 ECTS credits, European Credit Transfer System). We consider this subject suitable since it precisely seeks to develop competencies in the field of technologies and innovation management, implementing problem-solving and decision-making skills in training areas. In addition, among the competences to be developed in students is to analyze, understand and develop the possibilities offered by ICT today in the field of social and educational intervention, in addition to reflecting critically on the new demands and forms of social exclusion that presents the knowledge society to the profession of social educator.

In this subject there is a last thematic block called "MOOC courses and their repercussion and impact on the social scene", in which the characteristics of this phenomenon are presented theoretically and later a practical experience will be carried out in which students take different MOOC courses from different platforms and universities. The educational praxis results in the students having to present a metacognitive and reflexive contribution on the positive and negative characteristics of the MOOCs, according to the personal work they have done on them.

For this purpose, each university student designed and implemented an edublog inserting this didactic contribution. Different slogans were offered to carry out the work in the most effective way possible, accompanied by an explanatory video referring to the main characteristics of the MOOC courses that allowed them to identify positive and negative aspects.

Detailing the process, each student had to elaborate a personal edublog, within the subject already referred to and taught by the faculty of the Department of Education and Social Psychology, on the evidence of e-activities carried out during the academic semester. This product, the edublog, was compulsory and was valued with $20 \%$ of the final grade. One of its tabs corresponded to the work of analysis on the MOOC in order to determine its advantages/disadvantages in the socio-educational 
field. This was an after-school activity and was offered as a deadline for presentation one week before the end of the academic year.

In Figure 1, an edublog made by a student of this subject is presented as an example:

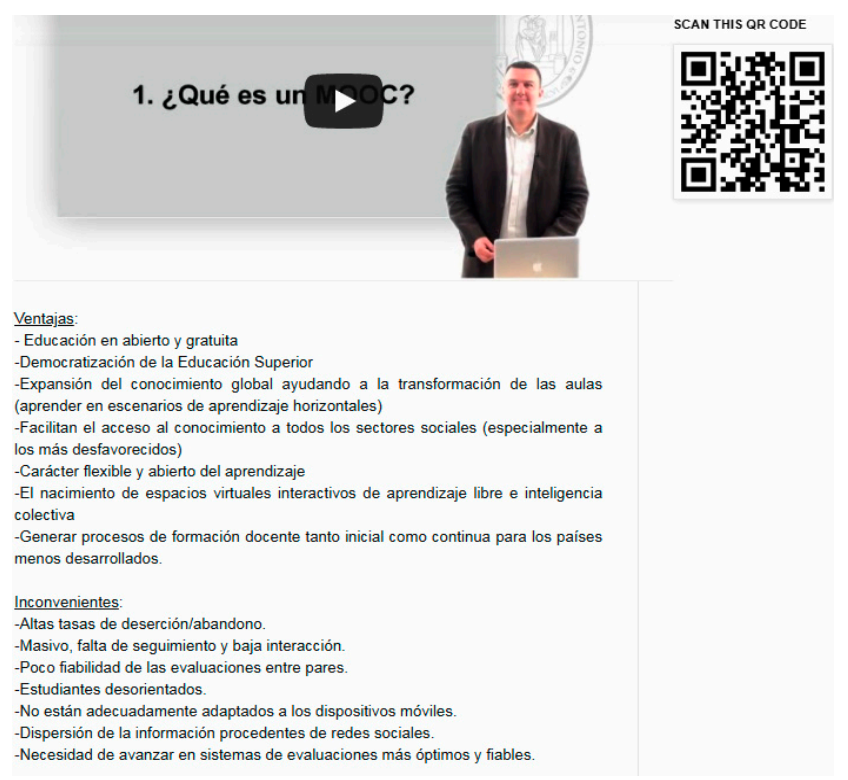

Figure 1. Edublog of a student in which she makes a metacognitive and reflexive analysis of the positive and negative aspects of the MOOC courses. Source: Own elaboration.

The sample $(n=218)$ was composed of 218 pre-service teachers who carried out this educational experience from 2015 to 2019 (Academic year 2015-2016: 53; Academic year 2016-2017: 54; Academic year 2017-2018: 56; Academic year 2018-2019: 55). The sample consisted of $68.59 \%$ women and $31.21 \%$ men. The average age was 21.24 years, as all students belonged to the same degree, the same course and studied the same subject. A total of 1052 frequencies were obtained, which highlighted the advantages they considered the MOOC courses offered in relation to other training proposals in the field of Higher Education. On the other hand, 910 frequencies were identified that pointed out the deficiencies, limitations and barriers found when taking these courses. This makes a total of 1962 frequencies. This broad sample offers us a valuable evaluation of what future teachers consider about the MOOC phenomenon.

In general, therefore, the objectives pursued are focused on (1) studying the students' perception of the most relevant positive aspects concerning the new training modalities of MOOCs, and (2) describing the main weaknesses of these courses.

\subsection{Study Design and Method}

The research methodology used was exploratory, qualitative and descriptive. It is part of the generic field of descriptive and ethnographic qualitative research methods through the analysis of learning objects and online interventions. Given the homogeneity of the sample (students of the same age, the same university and degree, and coming globally from a socioeconomic context with similar characteristics (it is a public university)) a specific study of these variables was not necessary.

To analyze the information obtained in the fieldwork, consisting of the dozens of documents prepared by the students (comments on the MOOC courses presented in personal edublogs), the most appropriate guidelines for documentary analysis were used in the context of qualitative methods [67-72]. To this end, a simplification of the information was carried out through the selection, grouping, categorization and coding of the collected data. During the coding, each textual unit was identified, analyzed and linked with its corresponding category through a mixed procedure (inductive-deductive). Subsequently, the frequency process began. Finally, the analysis process ended in which the different 
units of information collected were interpreted to guide the inference and interpretation phase of the results that will be presented.

Focusing on and detailing the analysis carried out, it should be emphasized that we obtained the 1962 frequencies offered by the students from the words or sets of meanings as registration units. This approach allows us to deal more deeply with a complex topic with high levels of interpretation that purely quantitative research alone cannot determine [73,74]. The development was organized in three phases: The first phase consists of an approach in which the contributions of the students were analyzed through the technique of data reduction and inter-rater coding. This phase constitutes the realization of rational procedures that consist of categorizing and coding the data, identifying and differentiating the units of meaning. A second phase consisted in the simplification and selection of the most important macrocategories according to the students. This process comprises several sub-phases: separation and identification of categories and classification, synthesis, grouping and coding of the units. Two evaluators participated in the coding process, coding the written and audiovisual interventions of the students throughout the academic years. Due to the high number of discursive units identified, the "Guetzkow $U$ " index was calculated, which measures the coincidence in the number of units identified by two independent evaluators and coders according to the following formula [75]:

$$
\mathrm{U}=(\mathrm{O} 1-\mathrm{O} 2) /(\mathrm{O} 1+\mathrm{O} 2)
$$

where $\mathrm{O} 1$ represents the number of units identified by encoder 1 and $\mathrm{O} 2$ represents the number of units reported by encoder 2. Subsequently, the synthesis process and the meeting of key representative categories were developed. Finally, a third phase was generated in which a coding process was carried out, carried out by the Atlas-Ti program, of the main advantages, difficulties and weaknesses associated with the same challenges as the "Memo" proposals, and an explanatory network of the main proposals.

The results of this phase, after three rounds of coding the "U of Guetzkow" index, obtained a good adjustment value (0.0073) showing a 95\% agreement between the units coded by the two evaluators. On the other hand, and although there is discussion in the literature about it, the Kappa index was calculated. According to the popular reference levels of strength of agreement measured, it reflected a result $(\kappa=81)$ classified as very good [76], p. 2. In general, the analysis methods used satisfied the characteristics we were looking for in the study, and allowed us to achieve the objectives pursued in a rigorous and reliable way.

\section{Results}

Once the analysis of the obtained data has been completed, we can carry out the presentation of the results and its interpretation. To facilitate its presentations, we have established two (2) frequency tables below, one with the principal characteristics that the students considered positive in relation to the MOOC (Table 1) and another collecting the characteristics that they estimated were negative or, in their case, improvable (Table 2).

There were 1052 frequencies collected focused on positive aspects in relation to MOOC courses. Its defining characteristics (such as free or open courses), were highlighted by future teaching professionals. Later we will carry out a specific analysis of each one of them. It should be noted that practically all of the collections were established by a high percentage of students. Only one was in the minority, the characteristic that it is possible to take several MOOC courses at the same time for the reason that they can be taken at any time. In the subsequent table of frequencies, focused on the negative characteristics, it can be seen that there are none so exceptional in this case.

In relation to the MOOC phenomenon, 910 frequencies were collected as negative or improvable. It is significant to note that most of the courses they took were in English. However, they did not find it a problem as we had initially anticipated. It should be taken into account that they took the courses in a different language than the one they are studying, which is Spanish. In general, it can be determined that in the total of frequencies the positive aspects are superior to the negative ones. 
However, the differences are not important, which denotes that the MOOC courses, globally, are not as successful as in their early years.

Table 1. Frequency table (includes relative and cumulative frequencies): Main positive features of MOOC courses.

\begin{tabular}{cccc}
\hline Positive Features of MOOC Courses & Frequency & Relative Fr. & Cumulative Fr. \\
\hline Free of charge & 190 & 0.18060837 & 190 \\
It contributes to the training of the disadvantaged & 153 & 0.14543726 & 343 \\
Offer time flexibility & 113 & 0.10741445 & 456 \\
Wide range of courses & 87 & 0.00285171 & 543 \\
Quality university content & 83 & 0.07889734 & 626 \\
Allow participation in discussion/debate forums & 82 & 0.07794677 & 708 \\
Certificates can be obtained & 81 & 0.07699620 & 789 \\
Collaborative social networking is offered & 72 & 0.06844106 & 861 \\
Training is online & 71 & 0.06749049 & 932 \\
There is no limit to the number of tuitions & 56 & 0.05323194 & 988 \\
Support for initial and continuing training & 41 & 0.03897338 & 1029 \\
Multimedia materials are used & 20 & 0.01901141 & 1049 \\
It is possible to take several courses at the same & 3 & 0.08269962 & 1052 \\
time & & 1 & \\
\hline Total & 1052 & & \\
\hline
\end{tabular}

Table 2. Frequency table (includes relative and cumulative frequencies): Main negative features of MOOC courses.

\begin{tabular}{cccc}
\hline Negative Features of MOOC Courses & Frequency & Relative Fr. & Cumulative Fr. \\
\hline Lack of pedagogical monitoring & 137 & 0.15054945 & 137 \\
Display material is standard & 120 & 0.13186813 & 257 \\
Inadequate evaluation system & 106 & 0.11648352 & 363 \\
Dispersion of information & 103 & 0.11318681 & 466 \\
There is a high drop-out rate & 91 & 0.10000000 & 557 \\
Requires great autonomy on the part of the student & 78 & 0.08571429 & 635 \\
Additional cost of the official certificate & 75 & 0.08241758 & 710 \\
Massive & 48 & 0.05274725 & 758 \\
Some MOOCs are not adapted & 44 & 0.04835165 & 802 \\
It requires technical knowledge & 34 & 0.03736264 & 836 \\
It is a new business model & 33 & 0.03626374 & 869 \\
Need for Internet access & 31 & 0.03406593 & 900 \\
Predominance of MOOC courses in English & 10 & 0.01098901 & 910 \\
\hline Total & 910 & 1 & \\
\hline
\end{tabular}

Taking into account the frequencies identified, it is possible to defend that the future teachers of the analyzed sample considered the following as positive characteristics of the MOOC courses: Quality university content; It is possible to take several courses at the same time; Certificates can be obtained; Allow participation in discussion/debate forums; Offer time flexibility; Multimedia materials are used; There is no limit to the number of tuitions; Free of charge; Training is online; It is possible to do many courses; It contributes to the training of the disadvantaged; Collaborative social networking is offered; Support for initial and continuing training.

On the other hand, those that they considered negative, or at least that could be improved or represent a significant barrier, were the following: Inadequate evaluation system; There is a high drop-out rate; Requires great autonomy on the part of the student; Lack of pedagogical monitoring; Display material is standard; Dispersion of information; Additional cost of the official certificate; Massive; It requires technical knowledge; Need for Internet access; Predominance of MOOC courses in English; Some MOOCs are not adapted; It is a new business model. 
It is possible to obtain much more information by working with percentages. For this purpose, Figure 2 shows the percentages concerning the contributions linked to the advantages offered by these training spaces:

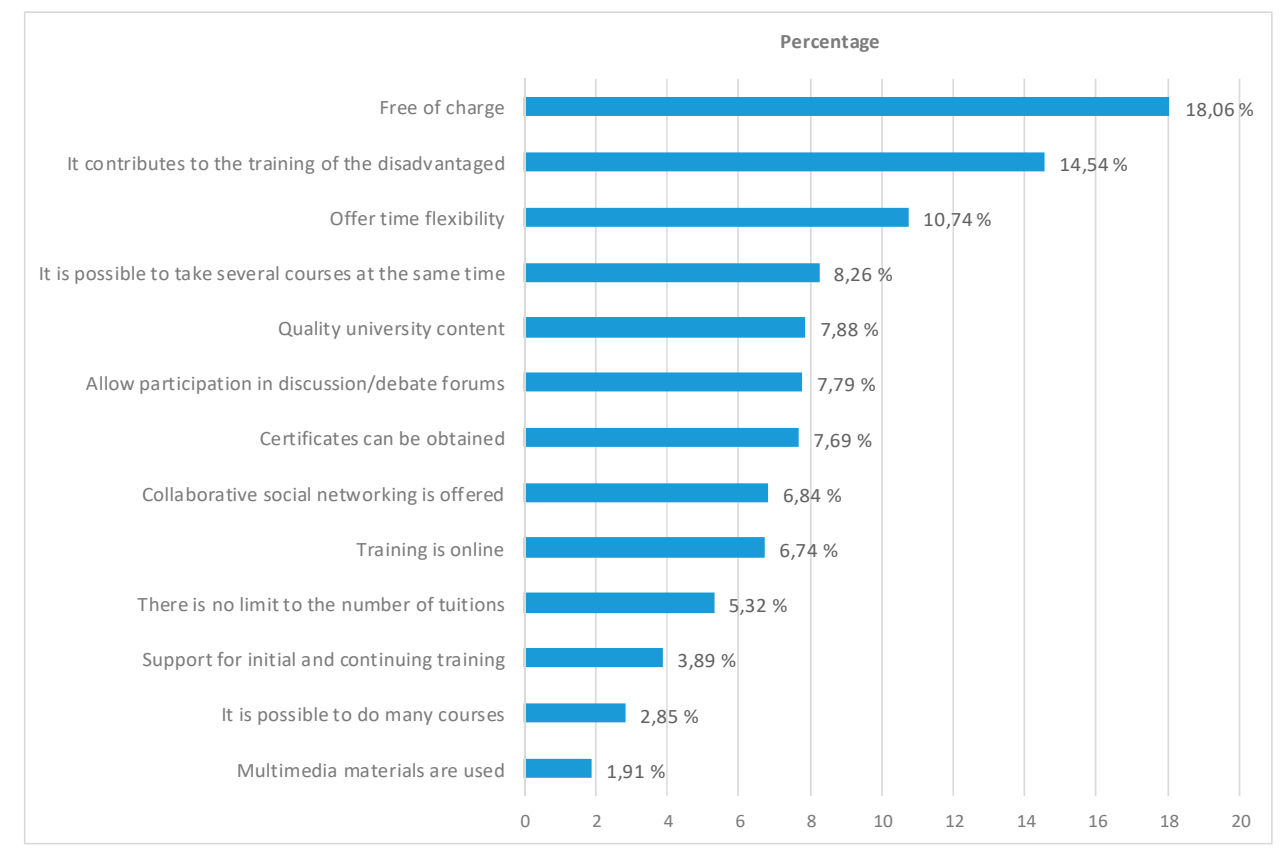

Figure 2. Percentage of the positive features of MOOC courses.

The percentage analysis allowed us to discover that the characteristic regarding MOOC courses that university students who are preparing to become future teachers appreciate the most is free usage $(18.6 \%)$. It is also very important, especially in the field of socio-educational contexts, that they establish as a relevant characteristic (the second most valued) that they contribute to the training of the most disadvantaged people, population layers or geographical spaces (14.54\%). The third most significant characteristic (10.74\%) is that MOOC courses are extremely flexible and can be temporarily adapted by the student to their needs.

Behind these characteristics, and highly valued in this type of training arising from the digital paradigm, there are others that are also highly appreciated, such as the fact that several courses can be taken at the same time $(8.26 \%)$, which speaks to us today of the demands in the field of education and the need for extensive training. MOOCs offer quality university content $(7.88 \%)$, in many cases from prestigious universities; that allow participation among students through forums and discussion groups $(7.79 \%)$, which generates a great wealth of communication and learning; and that academic certificates and recognition of the activity can be obtained (7.69\%). We initially thought this feature would be more prominent, especially due to the need to present evidence of all training activities both on an academic and professional level. It has caught our attention that there are other more valued aspects.

On a second plane, but also relevant, we find that these courses can lead to the creation of collaborative social networks $(6.84 \%)$ in this new context of collaborative and interactive learning generated in the virtualization of higher education. It is an online training offer (6.74\%), which allows access from any circumstance and place and there are no limits on the number of tuitions $(5.32 \%)$. They are useful for both initial and continuing training (3.89\%). All of these characteristics are closely related to new flexible, open and dynamic training spaces, clearly an alternative to traditional classroom processes.

Finally, and always as a positive feature of the MOOC courses, pre-service teachers also valued the fact that there is a very wide range of these courses $(2.85 \%)$ and that the materials presented on 
many occasions have been multimedia (1.91\%). In general, students have been very favorable towards MOOC courses and what they can imply, both in their training and in their presence as a training offer. They are also aware that this is a phenomenon of great interest in the field of higher education.

There are, however, other features of these courses that pre-service teachers consider to be negative or need to be improved. We present in Figure 3 the main ones that we have been able to obtain the percentage of:

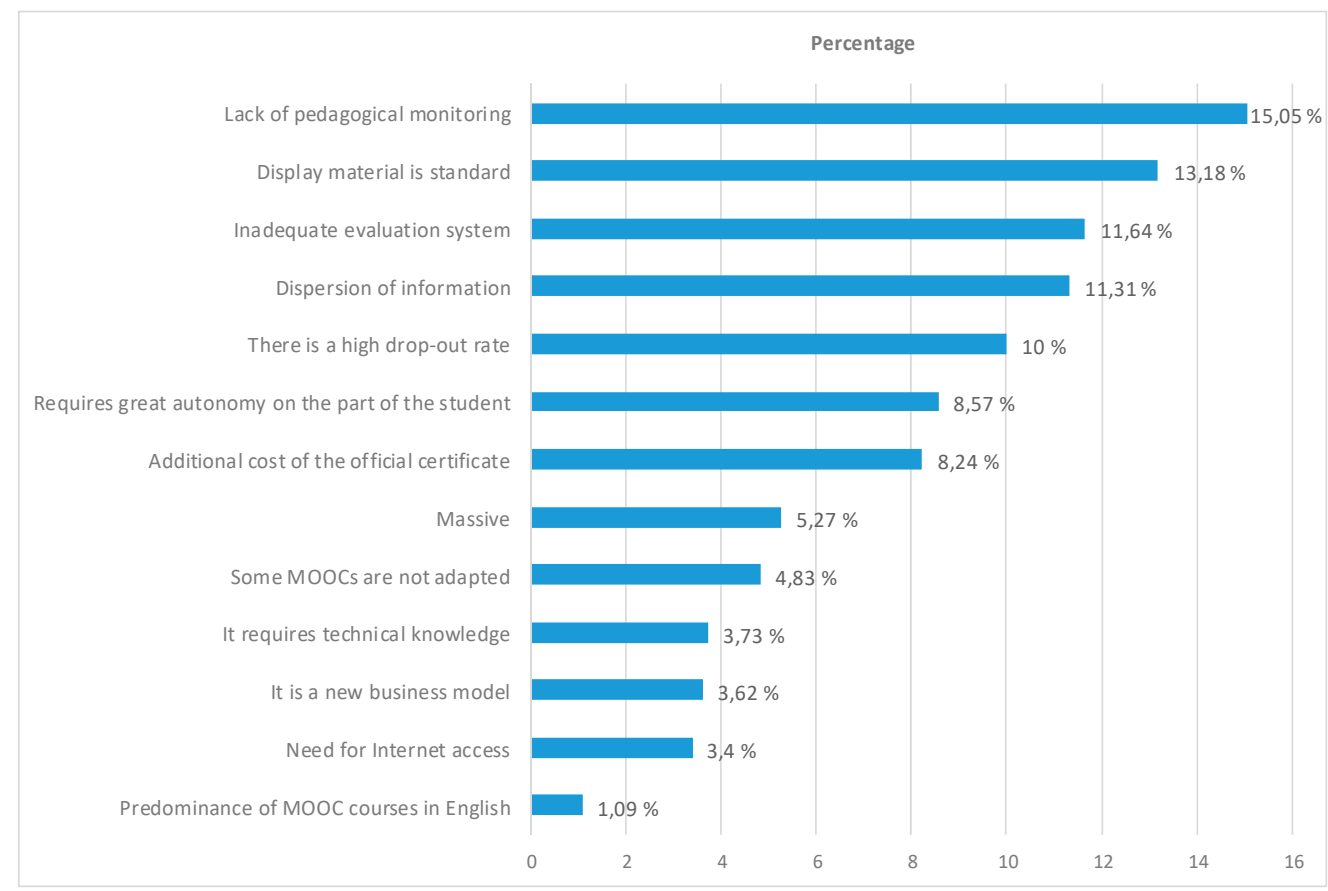

Figure 3. Percentage of the negative features of MOOC courses.

Among all of them, the one that stands out especially is the lack of pedagogical supervision of the teaching-learning process by teachers who teach MOOC courses $(15.05 \%)$. This is a very important piece of information, especially considering that those who are evaluating them are university students preparing to be teachers. It denotes that MOOCs are an interesting training offer but that it is alien to the specific fields of educational sciences. Also in this context, it is striking that the second characteristic they consider to be negative is that the material presented is very standard $(13.18 \%)$. It is a fact that agrees with the low percentage of future teachers who praised the use of innovative materials such as multimedia, as we saw previously. It is determined, therefore, that for the most part MOOC courses do not offer significant didactic or resource innovations. Which agrees, in the same way, with the third and fourth characteristics that they consider to be deficient, such as the inadequate evaluation processes $(11.64 \%)$ and the dispersion of information $(11.31 \%)$. Once again it is a didactic and pedagogical question, such as the evaluation of learning and the organization of content. In these aspects, the MOOC phenomenon has different gaps.

It is interesting to have verified, therefore, how the main problems or barriers generated by this phenomenon, in the opinion of the future teachers of the sample, are pedagogical in nature. In the background, although also very prominent, they find other problems such as the high drop-out rate $(10 \%)$; that require great autonomy on the part of the student $(8.57 \%)$, which affects precisely that lack of pedagogical advice mentioned above; the additional cost involved if someone wants an official certificate $(8.24 \%)$, which in essence would make them not completely free, one of the defining elements.

In the last part we find that another of its main and constituent characteristics is also seen as a disadvantage, that is, that they are massive $(5.27 \%)$, undoubtedly produced by courses in which there are hundreds of students enrolled and this thus makes it difficult for a quality didactic process. Some MOOCs are not properly adapted (4.83\%) and technical knowledge for proper monitoring is 
required $(3.73 \%)$. MOOCs are considered a business model (3.62\%) and require an Internet connection $(3.40 \%)$. We would like to emphasize that the fact that pre-service teachers considered it a disadvantage to think that this is a new business model was a matter of great interest since it allowed for different readings. In this case, they considered that the essential gratuity to the MOOCs was incompatible with the generation of a business model (for example derived from charging for the certificates), placing it in a context of idealization of the altruistic offer of these courses, thus considering it a negative element. However, it is clear that these concepts do not have to be in conflict with each other. In general, most of the problems or barriers listed in this block are structural or technical, and are far removed from the pedagogical disadvantages. Lastly, a striking fact is that they do not consider it a problem that most MOOC courses are in English (1.09\%).

Having presented the results obtained, it is possible to determine that, globally, the students in the sample analyzed find more strengths than weaknesses in the MOOC courses. It is, therefore, a phenomenon that they find it extremely interesting as a complementary educational option to their university studies. Although they have not been as successful as was predicted a few years ago, they are nevertheless an interesting and appreciated training proposal.

\section{Discussion}

The MOOC phenomenon already has, without a doubt, an indisputable presence in the higher education space. In addition, it is beginning to to be valued by students, especially those in the field of education-perhaps they will be future teachers-in a positive way. This new modality of expansion of knowledge through open, massive and online courses, which are part of the new educational fabrics of most prestigious international universities, can become a dynamic element of the curriculum in the biotic ecosystems of educational institutions, limited in time, spatially limited and often reserved for social elites [11,77-80]. Massive and open training represents a challenge for university institutions and the teaching community that must redefine the current methodological paradigm to enter new, more open, interactive, collaborative and ubiquitous curricular forms, in symbiosis with a more dynamic, holistic and human evaluation inserted in more flexible and diversified curricula adapted to the labor ecosystem [81-83]. With this, it will be possible for students to promote and facilitate the implementation of their own competence itinerary for their academic and professional development [84]. One of the most interesting elements is to understand how students manage time in these courses, on which more studies are needed [85]. Of course, it does not mean that everything is positive in MOOC courses, on the contrary, there are many elements and characteristics that can be clearly improved [86-91]. However, it is undeniable that, globally, they have represented an important advance in the field of distance education.

Our research has determined that one of the main advantages that this new philosophy and emerging trend of online training can offer, which due to its inherent nature of being free can help to reduce the digital divide of marginal social groups, is that anyone, regardless of their origin, can be trained. This is in line with what has been demonstrated by various authors [92-97]. Furthermore, MOOC courses can provide a sustainable and promising educational paradigm for distance learning [98-100]. On the opposite side, regarding weaknesses, it is worth noting their high dropout rate and poor tutoring and assessment systems in line with other research [30,101]. Similarly, these open mass networked courses can be the new sites of cognitive reflection and recreation, the new habitats for communication and innovation in university digital ecosystems and the seed of new mass learning scenarios [102]. Thanks to the philosophy of this training modality, it can lead to a democratization of higher education [103-105].

Our study supposes an approach to the problem from the perspective of future teaching professionals. It may be appropriate in the future to establish larger samples and in longer periods of time, as well as to extend the study to other countries, since in this case it has only been carried out in Spain. For example, a comparative study between Latin American countries could be carried out to establish whether the perception of MOOC courses is similar in this wide geographic space of 
common cultural characteristics or depends on the specific circumstances (economic, social, etc.) of each country. Methodologies that have been very positive from this comparative approach could also be used [106-110]. This methodology could also be applied to other countries in the international arena, we cannot forget that the MOOC phenomenon is global, precisely one of its defining characteristics.

\section{Conclusions}

Massive and open training represents a challenge for university institutions and their teachers who must redefine the current methodological paradigm to enter into new ways of designing more interactive, collaborative and ubiquitous educational materials, together with new, more dynamic and self-managed forms of evaluation [111,112]. For the University to be integrated into these new training spaces, it must adapt the conformation of its study plans from a broader and more diversified catalog of subjects that allow the student to create their own map of competencies within those of an academic or professional field. In this way, the concept of diversified learning takes on all the sense in contrast to the current uniformity of university programs. The trend should be to offer open programs in direct relation to the work, academic and professional world that position students before the possibility of creating a training itinerary that adapts to the necessary skills in a changing and diversified world open to new tools and widely interconnected spaces [113-115].

The research carried out has shown that, in the opinion of the Spanish students who have participated in the sample, future teachers, MOOC courses are valuable as teaching models in socio-educational contexts. They offer undoubted advantages such as their free service, training for disadvantaged groups, flexible hours, etc. However, its drawbacks with respect to other educational and training formats are also important. For example, it is considered that in these courses the student is not adequately monitored, that the population that is carried out in the apprenticeships is inadequate or, likewise, the great dispersion that sometimes occurs with the information presented. Mainly, in essence, these are problems of a pedagogical nature.

This is a very interesting aspect because one of the great challenges of the MOOC phenomenon, beyond its defining characteristics, is the development of pedagogical structures that allow the maximum potential of telematic environments to be obtained. Precisely the fact that there is a wide typology of MOOC courses (cMOOC, xMOOC, tMOOC, etc.) implies the creation of models that try to adapt this instructive reality, in the best possible way, to the educational and training needs of the users. Nor should it be forgotten that one of the greatest controversies regarding this modality of distance education has been generated by studies on the authentic possibilities of so-called connectivism, which, once again, is closely linked to essentially didactic and pedagogical questions. That is to say, and as has been reflected in this research, and shown to us by pre-service teachers, the principal improvements should be made not in that which is directly related to the technological or technical, for which there is practically no discussion, but rather with that which is essentially educational.

More studies are necessary to establish whether there are common patterns in terms of positive and negative elements in all MOOC courses as this would be decisive for their improvement. We are talking about new models born from the emergence of the digital paradigm that allow new educational scenarios of great interest and scope, which must be perfected to achieve maximum efficiency [116,117], it is special, as we have shown, in a pedagogical field above the technician. For this reason, research is so necessary that allows us to obtain direct information on their development and evolution in order to optimize, from a pedagogical and training point of view, the quality of these offers. What is fundamental for the processes of digitization and virtualization of higher education, towards which we are inevitably heading.

Author Contributions: Conceptualization, J.G.-G., E.L.-M.; methodology, J.G.-G., E.L.-M.; validation, J.G.-G., C.L.-P., J.Á.M.-L., E.L.-M.; formal analysis, J.G.-G., E.L.-M.; investigation, J.G.-G., E.L.-M.; data curation, J.G.-G., E.L.-M.; writing—original draft preparation, J.G.-G., C.L.-P., J.Á.M.-L., E.L.-M.; writing—review and editing, J.G.-G.; supervision, J.G.-G.; project administration, J.G.-G., C.L.-P., J.Á.M.-L., E.L.-M. All authors have read and agreed to the published version of the manuscript. 
Funding: This research received no external funding.

Acknowledgments: We thank the dozens of colleagues, university professors, who have selflessly helped us with the delivery of the questionnaire to the students in the different countries analyzed.

Conflicts of Interest: The authors declare no conflict of interest.

\section{References}

1. Tadesse, T.; Gillies, R.M.; Campbell, C. Assessing the dimensionality and educational impacts of integrated ICT literacy in the higher education context. Australas. J. Educ. Technol. 2018, 34. [CrossRef]

2. Khalid, M.S.; Pedersen, M.J. Digital exclusion in higher education contexts: A systematic literature review. Procedia-Soc. Behav. Sci. 2016, 228, 614-621. [CrossRef]

3. Birx, D.L. Rethinking Higher Education: Integration as a Framework for Change. New Dir. High. Educ. 2019, 185, 9-31. [CrossRef]

4. Klement, M. Models of integration of virtualization in education: Virtualization technology and possibilities of its use in education. Comput. Educ. 2017, 105, 31-43. [CrossRef]

5. Gyamfi, S.A.; Gyaase, P.O. Virtualization of university education: The impact of ICT-mediated learning environment on students' performance. Int. J. E-Serv. Mobile Appl. 2017, 9, 24-40. [CrossRef]

6. Ugur, N.G. Digitalization in higher education: A qualitative approach. Int. J. Technol. Educ. Sci. 2020, 4, 18-25. [CrossRef]

7. Matveeva, S.V.; Akatova, N.S.; Shcherbakov, Y.I.; Filinova, N.V. Digitalization of Higher Education and Professional Development of Educators: Technologies and New Opportunities. Amazon. Investig. 2020, 9, 77-86. [CrossRef]

8. Mertala, P. Paradoxes of participation in the digitalization of education: A narrative account. Learn. Media Technol. 2020, 45, 179-192. [CrossRef]

9. Awidi, I.T.; Paynter, M. The impact of a flipped classroom approach on student learning experience. Comput. Educ. 2019, 128, 269-283. [CrossRef]

10. Henderson, M.; Ryan, T.; Phillips, M. The challenges of feedback in higher education. Assess. Eval. High. Educ. 2019, 44, 1237-1252. [CrossRef]

11. Gómez-Galán, J.; Martín, A.H.; Bernal, C.; López-Meneses, E. MOOC Courses and the Future of Higher Education: A New Pedagogical Framework; River Publishers: Aalborg, Denmark, 2019.

12. Angarita, L.M.; Chiappe, A. Are ICT good partners for the development of creativity? A systematic review of literature. Int. J. Arts Technol. 2019, 11, 231-248. [CrossRef]

13. López-Gil, M.; Bernal, C. El perfil del profesorado en la Sociedad Red: Reflexiones sobre las competencias digitales de los y las estudiantes en Educación de la Universidad de Cádiz. Int. J. Educ. Res. Innov. 2019, 11, 83-100.

14. Bryndin, E. Creative innovative higher education of researchers with flexible skills and synergy of cooperation. Contemp. Res. Educ. Engl. Lang. Teach. 2019, 1, 1-6.

15. Banihashem, K.; Farokhi, S.; Shahalizadeh, M.; Mashhadi, M. The effect of e-learning on students' creativity. Interdiscip. J. Virtual Learn. Med Sci. 2020, 5, 53-61.

16. Fernández-Márquez, E.; Leiva-Olivencia, J.J.; López Meneses, E. Competencias digitales en docentes de Educación Superior. Rev. Digit. Investig. Docencia Univ. 2018, 12, 213-231. [CrossRef]

17. Matosas-López, L.; Aguado-Franco, J.; Gómez-Galán, J. Constructing an instrument with behavioral scales to assess teaching quality in blended learning modalities. J. New Approaches Educ. Res. 2019, 8, 142-165. [CrossRef]

18. Gómez-Galán, J. Media education in the ICT era: Theoretical Structure for innovative teaching styles. Information 2020, 11, 276. [CrossRef]

19. Jung, I. ICT-pedagogy integration in teacher training: Application cases worldwide. J. Educ. Technol. Soc. 2005, 8, 94-101.

20. Markauskaite, L. Exploring the structure of trainee teachers' ICT literacy: The main components of, and relationships between, general cognitive and technical capabilities. Educ. Technol. Res. Dev. 2007, 55, 547-572. [CrossRef]

21. Guzman, A.; Nussbaum, M. Teaching competencies for technology integration in the classroom. J. Comput. Assist. Learn. 2009, 25, 453-469. [CrossRef] 
22. Ali, W. The Efficacy of Evolving Technology in Conceptualizing Pedagogy and Practice in Higher Education. High. Educ. Stud. 2019, 9, 81-95. [CrossRef]

23. Gómez-Galán, J. La integración de la telemática en la escuela. Rev. Latinoam. Tecnol. Educ. 2002, 1, 47-59.

24. Dunn, T.J.; Kennedy, M. Technology Enhanced Learning in higher education; motivations, engagement and academic achievement. Comput. Educ. 2019, 137, 104-113. [CrossRef]

25. Markoff, J. Virtual and Artificial, but 58,000 Want Course. The New York Times, 16 August 2011; p. A11.

26. Swan, K.; Day, S.; Bogle, L. Metaphors for learning and MOOC pedagogies. In Proceedings of the Third ACM Conference on Learning Scale, Edinburgh, UK, 25-26 April 2016; pp. 125-128.

27. Saadatdoost, R.; Jafarkarimi, H.; Sim, A.T.; Hee, J.M. Understanding MOOC learners: Insights from participation in Coursera MOOC. Int. J. Web-Based Learn. Teach. Technol. 2019, 14, 93-112. [CrossRef]

28. Regalado, A. The Most Important Education Technology in 200 Years. MIT Technol. Rev. 2012, 116, 61-62.

29. Liyanagunawardena, T.; Adams, A.; Williams, S. MOOCs: A Systematic Study of the Published Literature 2008-2012. Int. Rev. Res. Open Distance Learn. 2013, 14, 202-227. [CrossRef]

30. Gómez-Galán, J.; Pérez-Parras, J. Luces y sombras del fenómeno MOOC: ¿representan una auténtica innovación educativa? Rev. Pedagog. 2017,36. [CrossRef]

31. Gómez-Galán, J.; Martín, A.H.; Bernal, C.; López-Meneses, E. Los MOOC y la Educación Superior. Nuevas Posibilidades Para la Innovación y la Formación Permanente; Octaedro: Barcelona, Spain, 2017.

32. Villa, A.; Poblete, M. Aprendizaje Basado en Competencias. Una Propuesta Para la Evaluación de las Competencias Genéricas; Mensajero: Bilbao, Spain, 2007.

33. Miles, J.; Nayak, P. Curriculum co-presences and an ecology of knowledges. Curric. Inq. 2020, 50, 99-104. [CrossRef]

34. Pulist, S.K. Open Educational Resources (Including MOOCs). Qual. Educ. 2020. [CrossRef]

35. Lee, C.; de Vries, W.T. Sustaining a culture of excellence: Massive Open Online Course (MOOC) on land management. Sustainability 2019, 11, 3280. [CrossRef]

36. Li, Z. Educational model of innovation and entrepreneurship based on the concepts of OBE and MOOC. In The International Conference on Cyber Security Intelligence and Analytics; Xu, Z., Parizi, R., Hammoudeh, M., Loyola-González, O., Eds.; Springer: Cham, Switzerland, 2020; pp. 589-596.

37. Rao, N.J. Outcome-based Education: An outline. High. Educ. Future 2020, 7, 5-21. [CrossRef]

38. Gómez-Galán, J. Internet: ¿realmente una herramienta educativa? In Actas de la I Conferencia Internacional de Educared: La Novedad Pedagógica de Internet; Beltrán, J.A., Ed.; Fundación Encuentro: Madrid, Spain, 2001.

39. Gómez-Galán, J. Media education as theoretical and practical paradigm for digital literacy: An interdisciplinary analysis. Eur. J. Sci. Theol. 2015, 11, 31-44.

40. López-Meneses, E.; Gómez-Galán, J. Prácticas universitarias constructivistas e investigadoras con software social. Praxis 2010, 6, 15-31.

41. Kanematsu, H.; Barry, D. ICT and the impact on education. In STEM and ICT Education in Intelligent Environments; Kanematsu, H., Barry, D., Eds.; Springer: Cham, Switzerland, 2016; pp. 33-36.

42. Johnson, L.; Adams, S.; Cummins, M.; Estrada, V.; Freeman, A.; y Ludgate, H. NMC Horizon Report; The New Media Consortium: Austin, TX, USA, 2013.

43. Reich, J.; Ruipérez-Valiente, J.A. The MOOC pivot. Science 2019, 363, 130-131. [CrossRef] [PubMed]

44. Siemens, G. Connectivism: A learning theory of the digital age. Int. J. Instr. Technol. Distance Learn. 2005, 2, 3-10.

45. Siemens, G. Massive Open Online Courses: Innovation in education? In Open Educational Resources: Innovation, Research and Practice; McGreal, R., Kinuthia, W., Marshall, S., Eds.; Commonwealth of Learning y Athabasca University: Vancouver, BC, Canada, 2013; pp. 5-15.

46. Bell, F. Connectivism: Its place in theory-informed research and innovation in technology—Enabled learning. Int. Rev. Res. Open Distance Learn. 2011, 12, 98-118. [CrossRef]

47. Clará, M.; Barberá, E. Learning online: Massive Open Online Courses (MOOCs), connectivism, and cultural psychology. Distance Educ. 2013, 34, 129-136. [CrossRef]

48. Renda, G.; Kuys, B. Connectivism as a Pedagogical Model within Industrial Design Education. Procedia Technol. 2015, 20, 15-19. [CrossRef]

49. Thota, N. Connectivism and the Use of Technology/Media in Collaborative Teaching and Learning. New Dir. Teach. Learn. 2015, 142, 81-96. [CrossRef]

50. Downes, S. Recent Work in Connectivism. Eur. J. Open Distance E-Learn. 2020, 22, 113-132. [CrossRef] 
51. Pomerol, J.C.; Epelboin, Y.; Thoury, C. MOOCs: Design, Use and Business Models; John Wiley \& Sons: New York, NY, USA, 2015.

52. Fidalgo, A.; Sein, M.L.; García-Peñalvo, F.J. From massive access to cooperation: Lessons learned and proven results of a hybrid xMOOC/cMOOC pedagogical approach to MOOCs. Int. J. Educ. Technol. High. Educ. 2016, 13, 24. [CrossRef]

53. Rincón, E.G.; Mena, J.; Ramírez, M.S.; Ramírez, R. The use of gamification in xMOOCs about energy: Effects and predictive models for participants' learning. Australas. J. Educ. Technol. 2020, 36, 43-59.

54. Bournissen, J.M.; Tumino, M.C.; Carrión, F. MOOC: Evaluación y medición de la calidad percibida. Int. J. Educ. Res. Innov. 2019, 11, 18-32.

55. McAuley, A.; Stewart, B.; Siemens, G.; Cormier, D. Massive Open Online Courses. Digital Ways of Knowing and Learning. In The MOOC Model for Digital Practice; University of Prince Edward Island: Charlottetown, PE, Canada, 2010.

56. Mackness, J.; Mak, F.J.; Williams, R. The ideals and reality of participating in a MOOC. In Proceedings of the 7th International Conference on Networked Learning, Aalborg, Denmark, 3-4 May 2010; pp. 266-274.

57. García-Sastre, S.; Idrissi, M.; Ortega, A.; Gómez-Sánchez, E. Uso de la colaboración y la gamificación en MOOC: Un análisis exploratorio. RIED. Rev. Iberoam. Educ. Distancia 2018, 21, 263-283. [CrossRef]

58. García-Barrera, A.; Gómez-Hernández, P.; Monge, C. La atención a la diversidad en los MOOC: Una propuesta metodológica. Educ. XX1 2017, 20, 215-233.

59. Schulmeister, R. As Undercover Student in MOOCs, Keynote "Campus Innovation und Jonferenztagung"; University of Hamburg: Hamburg, Germany, 2012.

60. Pérez-Parras, J.; Gómez-Galán, J. Conocimiento y empleo de los cursos MOOC en estudiantes de Magisterio españoles: Implicaciones en su formación. In Investigaciones Educativas Hispano-Mexicanas; López-Meneses, E., Maldonado, G.A., Marín, V., Vázquez-Cano, E., Eds.; AFOE: Seville, Spain, 2017; pp. 190-208.

61. Pérez-Parras, J.; Gómez-Galán, J. Knowledge and influence of MOOC courses on initial teacher training. Int. J. Educ. Excell. 2015, 1, 81-99. [CrossRef]

62. Gómez-Galán, J. Interacciones Moodle-MOOC: Presente y futuro de los modelos de e-learning y b-learning en los contextos universitarios. Eccos Rev. Científica 2017, 44, 17-31.

63. Dawna, E.; Eleanore, R.; Williams, M.; Brooks, S. Evaluating the validity and applicability of automated essay scoring in two Massive Open Online Courses. Int. Rev. Res. Open Distance Learn. 2014, 15, 83-98.

64. López-Meneses, E.; Vázquez-Cano, E.; Román, P. Análisis e implicaciones del impacto del movimiento MOOC en la comunidad científica: JCR y Scopus (2010-13). Comunicar 2015, 44, 73-80. [CrossRef]

65. Shah, D. By The Numbers: MOOC in 2015. How Has the MOOC Space Grown this Year? Get the Facts, Figures, and Pie Charts; Class Central: New York, NY, USA, 2015.

66. López-Meneses, E. El fenómeno MOOC y el futuro de la universidad. Front. Cienc. 2017, 1, 90-97. [CrossRef]

67. Miles, M.B.; Huberman, A. Qualitative Data Analysis: An Expanded Sourcebook; Sage: Newbury Park, CA, USA, 1994.

68. Bauer, M.W.; Gaskell, G. Qualitative Researching with Text, Image and Sound: A Practical Handbook for Social Research; Sage: Newbury Park, CA, USA, 2000.

69. Navarro, V. Constructing a teacher of qualitative methods: A reflection. Int. J. Soc. Res. Methodol. 2005, 8, 419-435. [CrossRef]

70. Ngulube, P. Qualitative data analysis and interpretation: Systematic search for meaning. In Addressing Research Challenges: Making Headway for Developing Researchers; Mathipa, E.R., Gumbo, M., Eds.; Mosala-Masedi Publishers \& Booksellers CC: Noordwyk, South Africa, 2015; pp. 131-156.

71. Padilla-Díaz, M. Phenomenology in educational qualitative research: Philosophy as science or philosophical science. Int. J. Educ. Excell. 2015, 1, 101-110. [CrossRef]

72. Lester, J.N.; Cho, Y.; Lochmiller, C.R. Learning to do qualitative data analysis: A starting point. Hum. Resour. Dev. Rev. 2020, 19, 94-106. [CrossRef]

73. Yin, R.K. Case Study Research: Design and Methods, Applied Social Research Methods Ser.; Sage: Newbury Park, CA, USA, 1989.

74. Maxwell, J.A. Qualitative Research Design: An Interactive Approach; Sage Publications: Thousand Oaks, CA, USA, 1996.

75. Holsti, O.R. Content Analysis for the Social Sciences and Humanities; Addison-Wesley: Reading, MA, USA, 1969. 
76. Xie, Q. Agree or disagree? A demonstration of an alternative statistic to Cohens kappa for measuring the extent and reliability of agreement between observer. In Proceedings of the Federal Committee on Statistical Methodology Research Conference, Washington, DC, USA, 4-6 November 2013; pp. 1-13.

77. Dillahunt, T.; Wang, Z.; Teasley, S.D. Democratizing higher education: Exploring MOOC use among those who cannot afford a formal education. Int. Rev. Res. Open Distrib. Learn. 2014, 15, 177-196. [CrossRef]

78. Hansen, J.D.; Reich, J. Democratizing education? Examining access and usage patterns in massive open online courses. Science 2015, 350, 1245-1248. [CrossRef]

79. González, S.G.; Del Pozo, F.; Paredes, W.; Del Pozo, H. Los MOOC: Tecnología y pedagogía emergente para la democratización del conocimiento. Rev. Perspect. 2018, 19, 215-224.

80. El Khadiri, K.; Labouidya, O.; El Kamoun, N.; Hilal, R. Success Factors In A Mooc Massive Device: Questions And Challenges. J. Theor. Appl. Inf. Technol. 2019, 97, 1167-1178.

81. Paiva, R.; Bittencourt, I.I. Helping mooc teachers do their job. In Researcher Links Workshop: Higher Education for All; Springer: Cham, Switzerland, 2017; pp. 52-67.

82. Castaño, J.; Kreijns, K.; Kalz, M.; Punie, Y. Does digital competence and occupational setting influence MOOC participation? Evidence from a cross-course survey. J. Comput. High. Educ. 2017, 29, 28-46. [CrossRef]

83. Watted, A.; Barak, M. Motivating factors of MOOC completers: Comparing between university-affiliated students and general participants. Internet Higher Educ. 2018, 37, 11-20. [CrossRef]

84. Veytia, M.G.; Gómez-Galán, J.; Morales, M.B. Competencias investigativas y mediación tecnológica en doctorandos de Iberoamérica. Int. J. Educ. Res. Innov. 2019, 12, 1-19.

85. Barba, P.G.; Malekian, D.; Oliveira, E.A.; Bailey, J.; Ryan, T.; Kennedy, G. The importance and meaning of session behaviour in a MOOC. Comput. Educ. 2020, 146, 103772. [CrossRef]

86. Baggaley, J. MOOC rampant. Distance Educ. 2013, 34, 368-378. [CrossRef]

87. Gómez-Galán, J. El fenómeno MOOC y la universalidad de la cultura: Las nuevas fronteras de la Educación Superior. Profr. Rev. Curric. Form. Profr. 2014, 18, 73-91.

88. Bartolomé, A.R.; Steffens, K. ¿Son los MOOC una alternativa de aprendizaje? Comunicar 2015, 22, 91-99.

89. Xing, W.; Tang, H.; Pei, B. Beyond positive and negative emotions: Looking into the role of achievement emotions in discussion forums of MOOCs. Internet High. Educ. 2019, 43, 100690. [CrossRef]

90. Guajardo, B.E.; Navarro, C.; Valenzuela, J.R. Systematic mapping study of academic engagement in MOOC. Int. Rev. Res. Open Distrib. Learn. 2019, 20, 114-139. [CrossRef]

91. Wang, W.; Guo, L.; He, L.; Wu, Y.J. Effects of social-interactive engagement on the dropout ratio in online learning: Insights from MOOC. Behav. Inf. Technol. 2019, 38, 621-636. [CrossRef]

92. Christensen, G.; Steinmetz, B.; Alcorn, B.; Bennett, A.; Woods, D.; Emanuel, E.J. The MOOC Phenomenon: Who Takes Massive Open Online Courses and Why? University of Pennsylvania: Philadelphia, PA, USA, 2013.

93. Daniel, J.; Vázquez-Cano, E.; Gisbert, M. The future of MOOCs: Adaptative Learning or Business Model? RUSC. Univ. Knowl. Soc. J. 2015, 12, 64-73. [CrossRef]

94. Gómez-Galán, J. Nuevos fenómenos educativos como objeto de investigación científica: De la mochila digital a los cursos MOOC. In Issues de Investigación Educativa en una era Global: Nuevas Fronteras; Ponce, O., Pagán-Maldonado, N., Gómez-Galán, J., Eds.; Publicaciones Puertorriqueñas Inc.: San Juan, PR, USA, 2018; pp. 181-198.

95. Méndez, A.G.; López, S.; Barra, E. Efectividad de los MOOC para docentes en el uso seguro de las TIC. Comunicar 2019, 61, 103-112.

96. Torres, T.; Vidal, M.A. MOOC y modelos de aprendizaje combinado. Una aproximación práctica. RIED Rev. Iberoam. Educ. Distancia 2019, 22, 325-343.

97. Mac Fadden, I.; López-Meneses, E.; Sarasola, J.L.; Gómez-Galán, J. Reflections on Investigating the Complexity of Social Cohesion in the era of Globalization; Eurytion Press: Badajoz, Spain, 2020.

98. O'Connor, K. MOOCs: Institutional policy and change dynamics in higher education. High. Educ. 2014, 68, 623-635. [CrossRef]

99. Ossiannilsson, E.; Altinay, F.; Altinay, Z. MOOCs as change agents to boost in-novation in higher education learning arenas. Educ. Sci. 2016, 6, 25. [CrossRef]

100. Ma, L.; Lee, C.S. Investigating the adoption of MOOC s: A technology-user-environment perspective. J. Comput. Assist. Learn. 2019, 35, 89-98. [CrossRef] 
101. Gómez-Galán, J. MOOC courses in the context of distance education: A new pedagogical approach. In Progress in Education; Nata, R.V., Ed.; Nova Science Publishers: New York, NY, USA, 2020.

102. Vázquez-Cano, E.; López-Meneses, E.; Méndez, J.M.; Suárez-Guerrero, C.; Martín, A.H.; Román, C.; Gómez-Galán, J.; Revuelta, J.; Fernández Sánchez, M.J. Guía Didáctica Sobre Los MOOC; AFOE: Seville, Spain, 2013.

103. Finkle, T.A.; Masters, E. Do MOOC pose a threat to higher education? Res. High. Educ. J. 2014, 26, 1-10.

104. Moura, V.F.; Souza, C.A.; Oliveira, J.D.; Viana, A.B. MOOCS' potential for democratizing education: An analysis from the perspective of access to technology. In European, Mediterranean, and Middle Eastern Conference on Information Systems; Themistocleous, M., Ed.; Springer: Cham, Switzerland, 2017; pp. 139-153.

105. Hood, N.; Littlejohn, A. Disruptive democratisers? The complexities and incongruities of scale, diversity and personalisation in MOOCs. In Ubiquitous Inclusive Learning in a Digital era; Ossiannilsson, E., Ed.; IGI Global: Hershey, PA, USA, 2018; pp. 1-28.

106. Zhang, L.; Amos, C.; McDowell, W.C. A comparative study of Internet addiction between the United States and China. Cyber Psychol. Behav. 2008, 11, 727-729. [CrossRef] [PubMed]

107. Christodoulides, G.; Michaelidou, N.; Siamagka, N.T. A typology of Internet users based on comparative: Evidence from eight countries. Eur. J. Mark. 2013, 47, 153-173. [CrossRef]

108. Drabowicz, T. Gender and digital usage inequality among adolescents: A comparative study of 39 countries. Comput. Educ. 2014, 74, 98-111. [CrossRef]

109. Gómez-Galán, J.; Vergara, D.; Ordóñez, E.; Veytia, G. Time of use and patterns of internet consumption in university students: A comparative study between Spanish-speaking countries. Sustainability 2020, $12,5087$. [CrossRef]

110. Vázquez-Cano, E.; Gómez-Galán, J.; Infante, A.; López-Meneses, E. Incidence of a non-sustainability use of technology on students' reading performance in Pisa. Sustainability 2020, 12, 749. [CrossRef]

111. Kongrugsa, N.; Nilsook, P.; Wannapiroon, P. Designing a knowledge review, based on connectivism of cloud computing for developing critical thinking. Int. J. Inf. Educ. Technol. 2016, 6, 492. [CrossRef]

112. Martín-Padilla, A.H.; López-Meneses, E.; Bernal, C.; Vázquez-Cano, E. The research observatory on the massive online open courses: Moocservatorio. Int. J. Educ. Res. Innov. 2018, 10, 27-50.

113. Concepción, J.D.; Veytia, M.; Gómez-Galán, J.; López-Meneses, E.L. Integrating the digital paradigm in higher education: Ict training and skills of university students in a european context. Int. J. Educ. Excell. 2019, 5, 47-64. [CrossRef]

114. López-Meneses, E.; Vázquez-Cano, E.; Gómez-Galán, J. Los MOOC: La globalizacion y la innovacion del conocimiento universitario. In Innovagogía 2014; Cobos, D., López-Meneses, E., Jaén, A., Martín, A.H., Molina, L., Eds.; AFOE: Seville, Spain, 2014; pp. 1475-1483.

115. Salas, Q.A.; Morales, M.B.; Villota, W.R.; López-Meneses, E. University students perceptions on the free mass training courses online. Int. J. Educ. Excell. 2019, 5, 63-77. [CrossRef]

116. Littenberg-Tobias, J.; Reich, J. Evaluating access, quality, and equity in online learning: A case study of a MOOC-based blended professional degree program. Internet High. Educ. 2020, 47, 100759. [CrossRef]

117. Lu, X.; Liu, X.W.; Zhang, W. Diversities of learners' interactions in different MOOC courses: How these diversities affects communication in learning. Comput. Educ. 2020, 151, 103873. [CrossRef]

(C) 2020 by the authors. Licensee MDPI, Basel, Switzerland. This article is an open access article distributed under the terms and conditions of the Creative Commons Attribution (CC BY) license (http://creativecommons.org/licenses/by/4.0/). 